\title{
New data for Isoxys of the Balang Fauna (Cambrian Stage 4), South China
}

\author{
Shual Liu, Jin Peng, RongQin Wen \& Boyan Liang
}

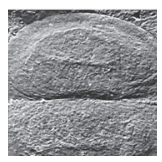

Isoxys Walcott, 1890 is a large bivalved arthropod taxon, commonly occurring in the Cambrian Series 2-3. Here, we report on a new group of Isoxys from the Balang Fauna (Cambrian Stage 4) of Guizhou, South China. It is composed of five species: Isoxys acutangulus (Walcott, 1908), I. auritus (Jiang, 1982), I. jianheensis sp. nov., I. globulus sp. nov., and Isoxys sp. Isoxys first appeared in the Chengjiang Biota (Cambrian Stage 3) located in the shallow-water Yangtze Platform in Yunnan, South China, and ranged to the Guanshan Biota (Cambrian Stage 4) above the Chengjiang Biota. The Balang Fauna of Guizhou Province is located in the transitional slope area of the deeper-water environments and is equivalent to the Guanshan Biota in age. The discovery of Isoxys in the Balang Fauna suggests that the genus, originally present in the shallow platform of Yunnan, migrated eastward to the deeper water shelf of Guizhou during the early Cambrian (Stage 4), becoming suited to a new ecological environment. The Isoxys assemblage of the Balang Fauna not only adds new taxa record for this genus but also provides new information for its palaeoecology, evolution, and geographic distribution. • Key words: Isoxys, Balang Fauna, Balang Formation, Cambrian, Guizhou, South China.

Liu, S., Peng, J., Wen, R. \& Liang, B. 2018. New data for Isoxys of the Balang Fauna (Cambrian Stage 4), South China. Bulletin of Geosciences 93(2), 147-162 (8 figures). Czech Geological Survey, Prague. ISSN 1214-1119. Manuscript received May 26, 2017; accepted in revised form February 19, 2018; published online June 12, 2018; issued June 30 , 2018.

Shuai Liu, Jin Peng (corresponding author), Rongqin Wen \& Boyan Liang, Resources and Environmental Engineering College, Guizhou University, Guiyang 550025, China; 2206873222@qq.com,gzpengjin@126.com, guasa@163.com, 605428978@qq.com

The large bivalved arthropod Isoxys Walcott, 1890 is a common taxon in the Burgess Shale-type biotas of the global Cambrian Series 2-3 and has a wide palaeogeographic distribution. It is known to occur in North America (Walcott 1908, Campbell \& Kauffman 1969, Simonetta \& Delle Cave 1975, Conway Morris et al. 1987, Butterfield \& Nicholas 1994, Williams et al. 1996, Briggs et al. 2008, García-Bellido et al. 2009b, Peel 2010, Stein et al. 2010), Australia (Daily 1956, Glaessner 1979, García-Bellido et al. 2009a), Europe (Richter \& Richter 1927, Vannier et al. 2005), Russia (Ivantsov 1990, 2005), and China (Jiang 1982; Hou 1987; Luo et al. 1999, 2006, 2008; Steiner et al. 2005; Zhao et al. 2005, 2011; Wang et al. 2010; Liu \& Lei 2013; Wen et al. 2015). It is characterized by prominent antero- and posterodorsal spines on a dorsal shield and double near-half-oval carapaces in outline (Fig. 1A). Based on the collection from the lower Cambrian Chilhowee Group in Tennessee, United States, Isoxys was first described by C. D. Walcott in 1890 as the type species Isoxys chilhoweanus. Subsequently, Walcott (1908) described Anomalocaris acutangulus from the Mt. Stephen Trilobite Beds (Canada). However, after specimens of Anomalocaris acutangulus were re-examined and compared with characteristics of Isoxys,
Anomalocaris acutangulus was redesignated as Isoxys acutangulus (Walcott, 1908), meanwhile, another species, I. longissimus from the Burgess Shale, was described by Simonetta \& Delle Cave (1975). Since then, more species and localities for Isoxys have been continually reported all over the world; many studies have recognized soft anatomy, such as visual organs, limbs, and posterior tagmosis morphology (Shu et al. 1995, Vannier \& Chen 2000, García-Bellido et al. 2009b, Vannier et al. 2009, Stein et al. 2010, Fu et al. 2011, Schoenemann \& Clarkson 2011, Huang \& Wang 2015). In addition, some researchers have provided information on the ontogeny and dimorphism of some species (Fu et al. 2014). Up until now, more than 17 species have been described.

The affinities of Isoxys have been controversial, especially its high-level taxonomic position. The reason for this is the lack of soft anatomic information, i.e. most specimens are preserved as isolated dorsal shields, often referred to as carapaces (Stein et al. 2010). Walcott (1890) placed Isoxys among small crustaceans based on its isolated dorsal shields. Generally, the cephalosome of crustaceans has 2 pairs of large anterior appendages; Isoxys, however, only has 1 pair of great appendages, which distinguishes it from crustaceans. Meanwhile, some scholars have placed 
Isoxys within Branchiopoda (Luo et al. 1999). However, Branchiopoda also have 2 pairs of large appendages, as they are crustaceans.

Despite the debates, Isoxys was placed within the "great-appendage" arthropods as a sister taxon of the anomalocaridid (Vannier et al. 2009). However, this hypothesis is challenged by the appendage segmentation of Isoxys, which differs from that of other "great-appendage" taxa (Fu et al. 2011). Another view is that all species of Isoxys may not be congeneric (Stein et al. 2010, Fu et al. 2011). Some researchers have evaluated their morphology and coded these taxa in extensive cladistics analyses, indicating that many species of Isoxys belong to the most basal arthropod taxa (Bergström et al. 2008, Legg et al. 2012, Legg \& Vannier 2013, Legg \& Caron 2014). The discovery of soft part of Isoxys has prompted a reconsideration of the affinities of this group; however, additional knowledge and evidence of the great appendages, especially the proximal parts, are needed to resolve the systematic position of Isoxys (García-Bellido et al. 2009b). In this paper, the higherlevel affiliations of the arthropod genera are still left open.

Isoxys has a wide geographic distribution in the Cambrian of South China, aside from the Chengjiang and Guanshan Biotas of Yunnan (Hou 1987, Luo et al. 1999,
Vannier \& Chen 2000). It also occurs in the Niutitang, Balang, and Kaili Biotas of Guizhou (Steiner et al. 2005, Zhao et al. 2005, Peng 2009). Although Isoxys from Guizhou has not been systematically studied, specimens of Isoxys are illustrated or recorded in some documents (Steiner et al. 2005; Zhao et al. 2005, 2011; Peng 2009). Here, we report on a new group of Isoxys from the Balang Fauna. The Balang Fauna is a Burgess Shale-type Biota from the Cambrian Series 2 of Guizhou (Peng et al. 2005) that includes representatives of 8 major groups, such as porifer-chanceleoriids, sponges, cnidarians, brachiopods, priapulids, mollusks, arthropods, and echinoderms, as well as many algae and trace fossils (Peng 2009). Since the Balang Formation has a wide distribution in Guizhou, 9 localities of the Balang Fauna have been found (Peng 2009; Ma et al. 2011; Peng et al. 2012a, b; Zhao et al. 2015; Shen et al. 2016). Isoxys from the Balang Fauna was first recognized as only one species, I. auritus, in one locality, based on a specimen with a counterpart in the Jiaobang section of the Balang Formation near Jiaobang Village, Jianhe County (Peng 2009, Peng et al. 2012b). A new collection from the Lazizhai section of the Balang Formation near Lazizhai Village, Jianhe County, contains more than 300 specimens of Isoxys, which display a diverse
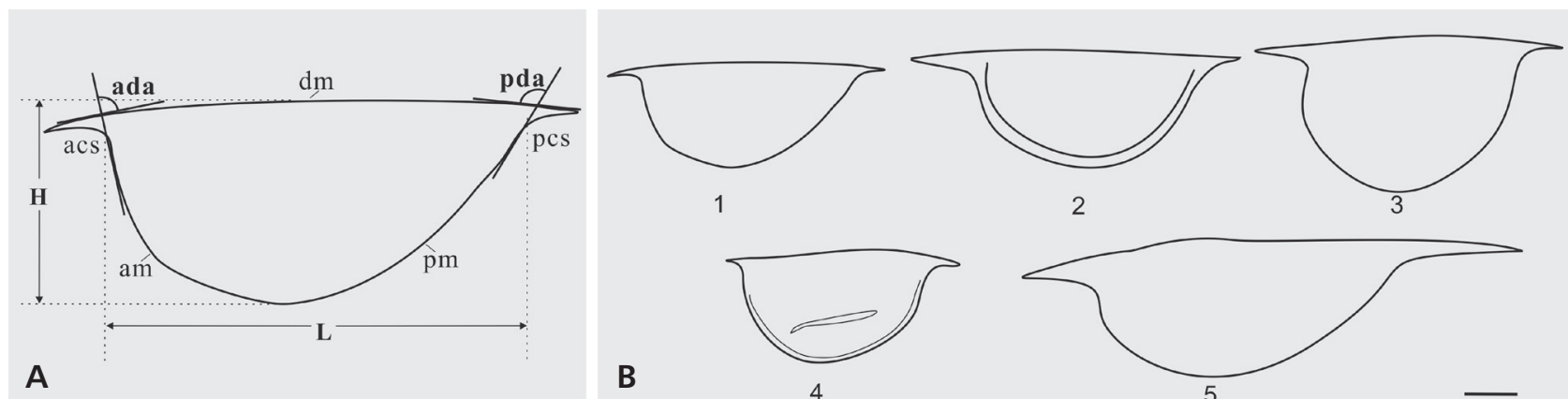

2

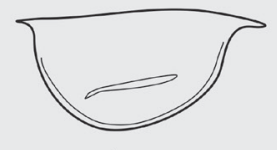

4
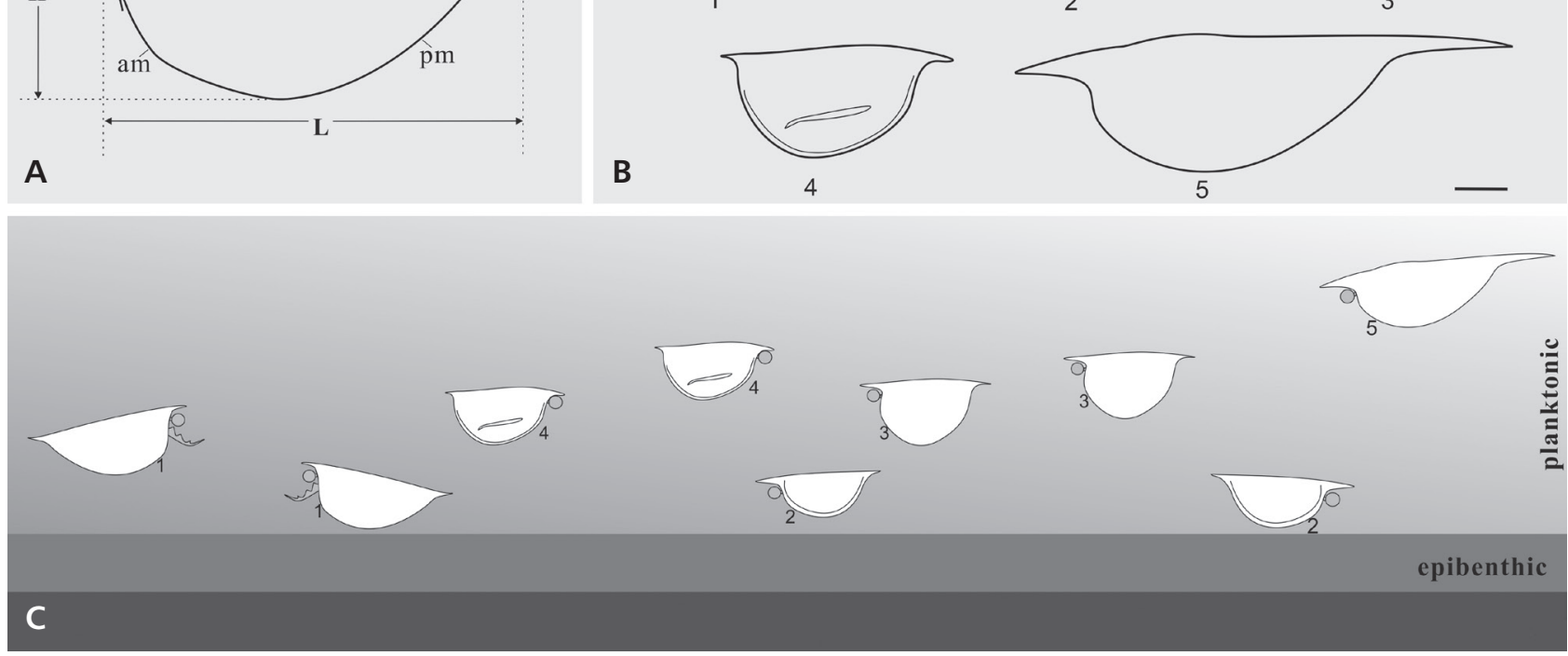

Figure 1. Isoxys species from the Balang Fauna of Guizhou, South China. - A - drawing showing the morphological terminology of a valve of I. acutangulus (Walcott 1908) corresponding to Fig. 4A. Abbreviations of morphologic terms mostly follow Vannier et al. (2009) and Fu et al. (2014): $\mathrm{acs}=$ anterior cardinal spine; $\mathrm{ada}=$ angle between anterior spine axis and anterior margin; am $=$ anterior ventral margin; $\mathrm{dm}=\mathrm{dorsal}$ margin; $\mathrm{L}=\mathrm{valve}$ length (exclusive cardinal spines); $\mathrm{H}=$ valve height; pcs = posterior cardinal spine; pda = angle between posterior spine axis and posterior margin; $\mathrm{pm}=$ posterior ventral margin. $・ \mathrm{~B}$ - outline of the 5 studied species of Isoxys. Abbreviations: $1=$ I. acutangulus (Walcott 1908); $2=$ I. auritus (Jiang, 1982); $3=I$. jianheensis sp. nov.; $4=I$. globulus sp. nov.; $5=I$. sp. Scale bar represents $5 \mathrm{~mm}$. $\bullet \mathrm{C}-$ presumed reconstructions and possible position in the water column of the 5 species of Isoxys. 

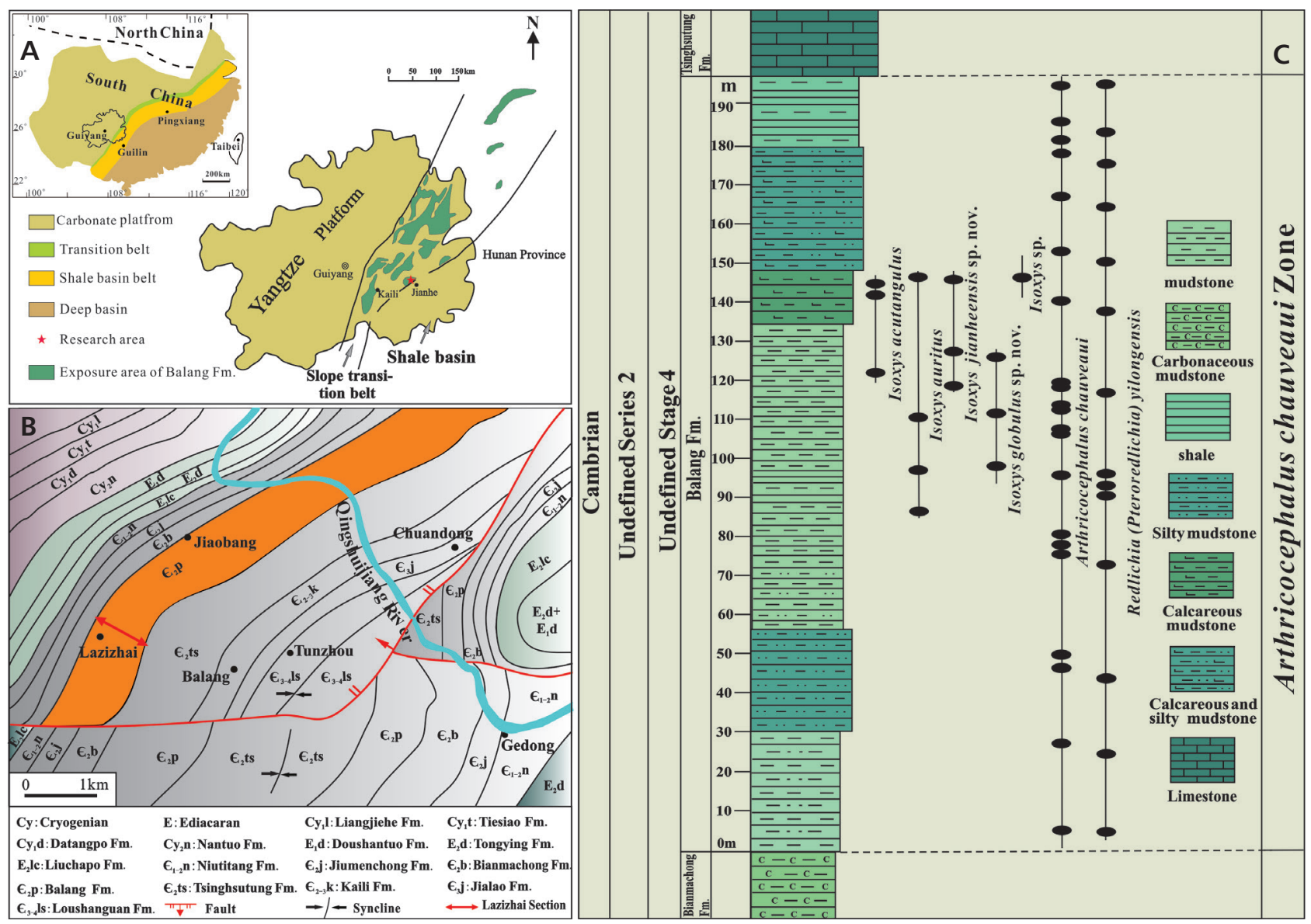

Figure 2. A - geographic extension of the Balang Formation (green shades). B - geological map of the Gedong Region, Jianhe Country, Guizhou Province (after Zhao et al. 2001), and location of the Lazizhai section of the Balang Formation. • C - stratigraphy of the Lazizhai section (Balang Formation) and distribution of Isoxys species and some trilobites.

assemblage, including five species: Isoxys acutangulus (Walcott, 1908), I. auritus (Jiang, 1982), I. jianheensis sp. nov., I. globulus sp. nov., and Isoxys sp. (see Fig. 1). It is known that I. acutangulus first appeared in the Burgess Shale Biota of Canada (Walcott 1908, Simonetta \& Delle Cave 1975), and this species from the Balang Fauna extends its geographic range. I. auritus is a common species in the Chengiiang Biota from the shallow-water platform of Yunnan. The discovery of this species of the Balang Fauna indicates that species originally present in the shallowwater platform migrated eastward to the deep-water area of Guizhou, adapting to a new ecological setting. The Isoxys assemblage from the Balang Fuana not only adds new records but also provides some new information regarding its palaeoecology, evolution, and geographic distribution.

\section{Geological setting}

The Balang Formation is exposed in eastern Guizhou Province and western Hunan Province, China, located in the transitional slope belt between the Cambrian Yangtze Platform and Jiangnan Basin (Zhou et al. 1979; Yin 1987, 1996; see Fig. 2A). The lithology of the formation varies but is dominated by greenish-grey shale and calcareous mudstone shale with intercalations of thin-bedded argillaceous carbonates. The thickness of this formation varies greatly throughout the emergence strata, from $100 \mathrm{~m}$ to more than $658 \mathrm{~m}$ (Yin 1987). The formation overlies the black shale of the Bianmachong Formation (Cambrian Stage 3) and underlies interbedded shale carbonates and shales of the Tsinghsutung (also published as Qingxudong) Formation (Cambrian Stage 4). In general, the Balang Formation represents a shallowing upward sequence toward its contact overlaying the Tsinghsutung Formation (Peng et al. 2012c).

The biostratigraphic framework of the Balang Formation was first described by Zhou et al. (1980), with trilobites indicative of the Arthricocephalus Zone in the lower Balang Formation and trilobites indicative of the Arthricocephalites-Changaspis-Balangia Assemblage Zone in the upper Balang Formation. Subsequently, 
Yin (1987) modified the name of the upper biozone as the Arthricocephalites-Changaspis Assemblage Zone. Since then, the work has been revised several times. It has been described from 1 genus-level assemblage zone (Yin 1996) up to 3 or 4 species-level zones (Yuan et al. 2001, 2002, 2006) and 1 species-level assemblage zone (Peng 2009, Qin et al. 2010). Most recently, Yan et al. (2014) included the entire Balang Formation as a single species-level zone, that is, the Arthricocephalus chauveaui Zone. The Balang Formation is equivalent to the Qiandongian early Duyunian of the Cambrian stratigraphic system of China in slope facies (Peng \& Babcock 2001). According to the criteria for correlation in South China, the Balang Formation is equivalent in age to the Wulongqing Formation in Yunnan Province (Luo 1994, Luo et al. 2008, Peng et al. 2010). Arthricocephalus chauveaui Bergeron, 1899, Changaspis elongata Lee in Chien, 1961 and Arthricocephlites intermidum Zhou in Lu et al. 1974, which are common in the Balang Formation (Shen et al. 2016), are known from the lower Cambrian Henson Gletscher Formation of Greenland (Blaker \& Peel 1997). However, according to correlation using three genera of corynexochid trilobites, the Balang Formation and part of the Henson Gletscher Formation are equivalent in age (Peng et al. 2016). Moreover, the Balang Formation contains abundant Redlichia (Pteroredlichia) chinensis (Walcott 1905) and correlates with the lower part of the Ordian of the Cambrian of Australia (Öpik 1970, Nedin 1995), and consequently correlates with that of the Guanshan Fauna and Emu Bay Shale Fauna (Nedin 1995, Hu et al. 2008, Luo et al. 2008, Peng et al. 2010).

The Lazizhai section of the Balang Formation near Lazizhai Village, Jianhe County, Guizhou Province, China, is a very fossiliferous unit. Here, the formation is $192 \mathrm{~m}$ thick and is exposed along a mountain ridge in which the Balang Fauna occurs in the middle and upper parts of the formation (Fig. 2B). Lithologically, the Balang Formation in this section can be divided into 2 members: the upper part is composed of greenish-yellow silty mudstone, and the lower part consists of greenish-grey siltstone, silty mudstone, and shale. The Balang Fauna occurs in the upper part (Fig. 2C). Isoxys specimens occur $95-150 \mathrm{~m}$ away from the bottom of the formation, associated with other components of the Balang Fauna, Guizhoueocrinus yui Zhao et al., 2007; Tuzoia sinensis Pan, 1957; palaeoscolecids; and the trilobites Redlichia (Pteroredlichia) chinensis (Walcott, 1905); Arthricocephalus chauveaui Bergeron, 1899; and Arthricocephalites xinzhaiheensis Chien \& Lin in Lu et al. 1974.

\section{Material and methods}

All Isoxys specimens (Figs 3-7) described here are deposited in the Guizhou Research Center for Paleontology,
Guizhou University, Guiyang, China. Specimens with the prefix JLS were collected from the Lazizhai section of the Balang Formation near Lazizhai Village, Jianhe County, Guizhou Province, China.

Specimens were examined and imaged using standard light microscopy, digital macrophotography [Canon Rebel Xsi (450D) with a Canon $60 \mathrm{~mm} \mathrm{f} / 2,8]$. Digital macrophotographs were stacked and rendered using Photoshop and CorelDraw software.

\section{Systematic paleontology}

Phylum Arthropoda von Siebold, 1848

Class, Order, and Family uncertain

\section{Genus Isoxys Walcott, 1890}

Type species. - Isoxys chilhoweanus Walcott, 1890.

Diagnosis. - Emended. Modified from Williams et al. (1996), Vannier \& Chen (2000), and García-Bellido et al. (2009b). Bivalved arthropod. Unmineralized carapace, semicircle, bivalved carapace connected in dorsal line (valves conjoined by a narrow band of cuticle; absence of articulating hinge), dorsal line straight or slightly convex in mid-position, dorsal line extends in frontto-back orientation to form long anterior and posterior cardinal spines. Lateral view weakly preplete to postplete, valve surface smooth or ornament expressed as uniform microreticulation or longitudinal striae or granulose. No dorsal spine or marginal spine, ventral margin smooth, or a very narrow lateroventral marginal ridge, or narrow to broad doublure present. Some species have a pair of large spherical stalk eyes and a pair of uniramous frontal appendages. Segments of the body trunk are less clear. Each segment has a pair of biramous appendages, which appear to consist of a pair of short segmented endopods and longer paddle-like exopods fringed with setae.

Occurrence. - North America, Europe, Siberia, Greenland, Australia, and China; Cambrian Series 2-3.

\section{Isoxys acutangulus (Walcott, 1908)}

Figure 3

1908 Anomalocaris acutangulus sp. nov.; Walcott, p. 13, pl. 2: 5 .

1928 Anomalocaris acutangula Walcott, 1908. - Walcott, p. 320.

1975 Isoxys acutangulus (Walcott, 1908). - Simonetta \& Delle Cave, p. 6, pl. 5: 6, pl. 54: 3, 4, 6-9 [non 1 (=Burgessia bella)].

1986 “shrimp". - Collins 1986, p. 37, fig. 4. 

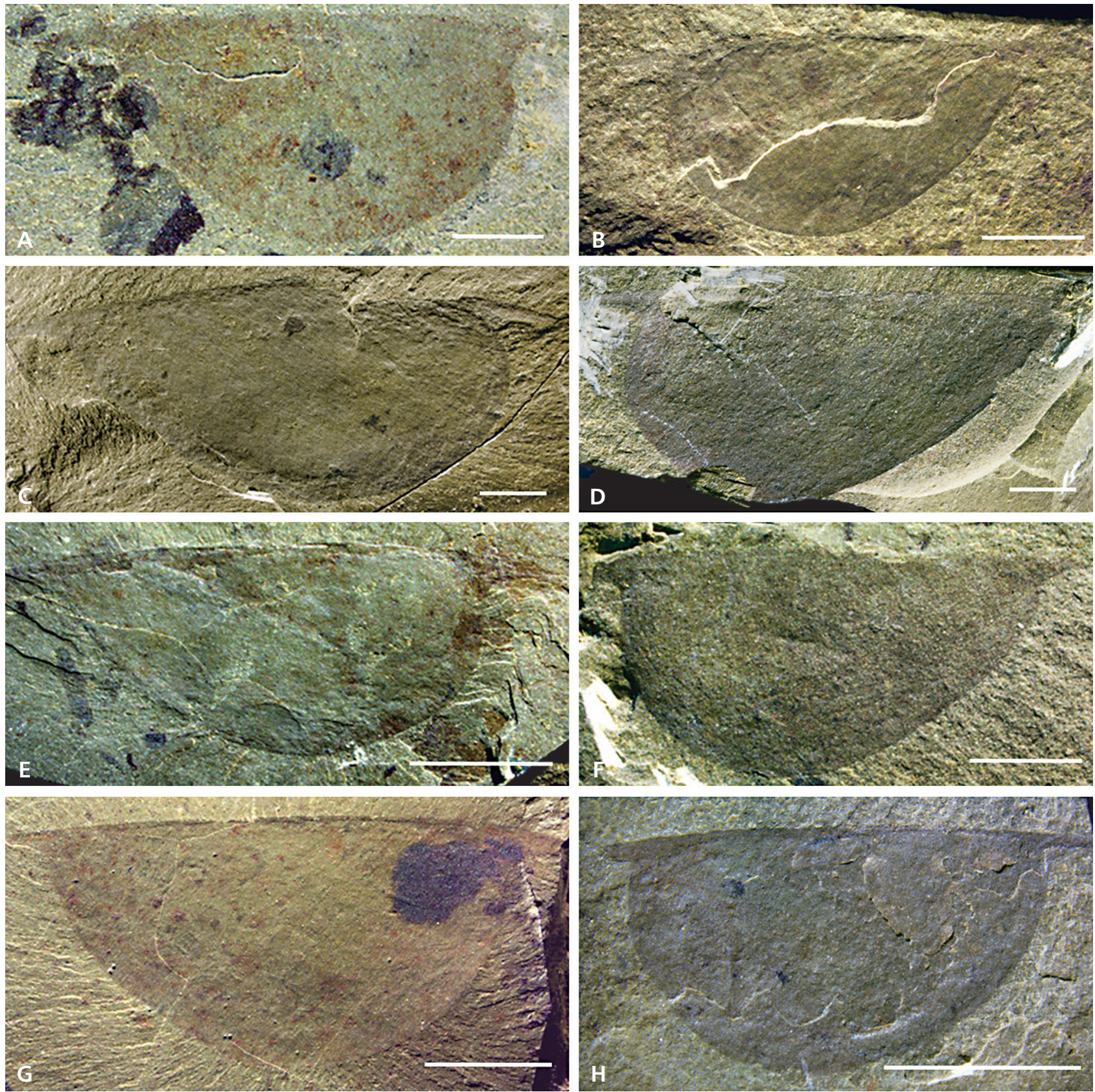

Figure 3. Isoxys acutangulus (Walcott, 1908), Lazizhai section, Balang Formation (Cambrian Stage 4) near Lazizhai Village, Jianhe County, Guizhou Province, China. All specimens are preserved only as hard shells without any soft parts. A - incomplete right valve with strong rostrum under acs, a thickshell, surface layer partially falling off, JLS170-579; B - complete left valve with a thick shell, surface layer half falling off, JLS170-764; C - nearly complete right valve with strong rostrum under acs, JLS85-663; D - incomplete left valve with strong rostrum under acs, JLS170-1889; E - complete right valve with strong rostrum and cardinal spines, JLS170-682; F -incomplete left valve, JLS170-1755; G - complete right valve, JLS170-1528; $\mathrm{H}$ - complete left valve, juvenile individual, JLS170-680. Scale bars represent $5 \mathrm{~mm}$.

1991 Isoxys acutangulus (Walcott, 1908). - Delle Cave \& Simonetta, fig. 20f.

1991 "shrimp". - Delle Cave \& Simonetta, fig. 23d.

1994 Isoxys acutangulus (Walcott, 1908). - Briggs et al., p. 149 , pl. 102.

2001 Isoxys acutangulus (Walcott, 1908). - Donovan \& Lewis, fig. 1f. 2009b Isoxys acutangulus (Walcott, 1908). - García-Bellido et al., p. 703, fig. 2.

2009 Isoxys acutangulus (Walcott, 1908). - Vannier et al., p. 2570 , fig. 2 .

Type species. - The type material consists of 2 specimens from the Mt. Stephen Trilobite Beds, which occur within 
the Campsite Cliff Shale Member, Burgess Shale Formation (Fletcher \& Collins 1998). These are USNM 56521 (part and counterpart) and USNM 56521B. No holotype was designated in the original description by Walcott (1908: 13) (see García-Bellido et al. 2009b).

Material. - Over 120 specimens, most preserved as part and counterpart, 14 of them nearly complete, only 6 preserved the entire length of both cardinal spines; 25 of them preserved the anterior or posterior cardinal spines, other only preserved valve or partial valve.

Diagnosis. - Isoxys with strong amplete outline; relatively short, slightly droopy anterior cardinal spine; and very short posterior spine. Cardinal spines of each valve fold, joining to form a strong anterior and posterior rostrum; no lineated or reticulated micro-ornament on carapace (García-Bellido et al. 2009b).

Description. - Carapaces medium sized and semicircular, valve length ranges from 15.46 to $50.19 \mathrm{~mm}$ (excluding cardinal spines), and height from 8.78 to $26.16 \mathrm{~mm}$. L:H ratio from 1.76 to 1.92 . Anterior cardinal spine long and sharp with a thick base; the longest is $7 \mathrm{~mm}$ with a maximum thickness $c a .2 .5 \mathrm{~mm}$ at the base. Posterior cardinal spine in short; the longest is $5 \mathrm{~mm}$ with a maximum thickness $c a .1 .5 \mathrm{~mm}$ at the base. Greatest height located slightly anteriorly, near valve mid-length; anterior ventral margin more inflated than the posterior one (preplete outline). Ventral margin tapers regularly beyond the mid-length line toward the posterior cardinal spine. Carapace smooth.

Remarks. - Isoxys acutangulus differs from all congeneric species by its relatively short cardinal spines (see Vannier \& Chen 2000), and does not show any lineated or reticulated microornament, as seen on I. auritus or I. curvirostratus. I. acutangulus is, so far, the species that displays the best-preserved soft-bodied features (e.g. visual and digestive organs, full series of appendages) (GarcíaBellido et al. 2009b). New specimens from the Balang Formation referred to this species have been examined. All preserved characteristics agree with the original material of I. acutangulus from the Stephen Formation (Cambrian Stage 5) of British Columbia, western Canada (see Vannier \& Chen 2000, García-Bellido et al. 2009b, Vannier et al. 2009). However, the material from the Balang Formation lacks soft-parts, and individuals are generally larger than those from the Burgess Shale Biota. Perhaps this is because the species from Guizhou lived in an ecological environment different from that of British Columbia; or, we speculate that this species evolved by getting smaller.

Occurrence. - British Columbia, western Canada, the
Stephen Formation (Cambrian stage 5); Lazizhai Village, Jianhe County, Guizhou Province, South China, the Balang Formation (Cambrian Stage 4).

\section{Isoxys auritus (Jiang, 1982)}

Figure 4

1982 Cymbia auritus; Jiang in Luo et al., p. 265, 29, fig. 16. 1987 Isoxys auritus (Jiang, 1982). - Hou, pp. 286-292.

1995 Isoxys auritus (Jiang, 1982). - Shu et al., pp. 333-342, figs $1-5$.

1996 Isoxys auritus (Jiang, 1982). - Chen, p. 181, figs 240, 241.

1997 Isoxys auritus (Jiang, 1982). - Chen \& Zhou, p. 65, fig. 94.

1999 Isoxys auritus (Jiang, 1982). - Luo et al., pp. 13, 66, figs $1-4$.

1999 Isoxys auritus (Jiang, 1982). - Hou et al., p. 101, fig. 140.

2004 Isoxys auritus (Jiang, 1982). - Chen, p. 253, figs 392, 393.

2003 Isoxys auritus (Jiang, 1982). - Hou et al., p. 116, figs 16.14, 16.15 .

2011 Isoxys auritus (Jiang, 1982). - Schoenemann \& Clarkson, pp. 223-230, figs 1-3.

2014 Isoxys auritus (Jiang, 1982). - Fu et al., pp. 975-982, figs 2-7.

Material. - 52 specimens, 6 complete; the other 46 have partial valves preserved.

Diagnosis. - Isoxys with valves of medium size, ventral outline half-elliptical, anteriorly wide. Dorsal line straight or slightly domed at mid-length. Extended cardinal spines thin and elongate; anterior and posterior cardinal spines sub-equal in length. Ornaments on valves consist of fine lines and reticulations (after Hou et al. 2003 and Fu et al. 2014).

Description. - Valve are medium sized, elongate, and elliptical in outline. Length of valves ranges from 12.21 to $54.4 \mathrm{~mm}$ (excluding cardinal spines), and height from 5.96 to $26.48 \mathrm{~mm}$; L:H ratio varies from 1.95 to 2.05 . Greatest height located before mid-length (amplete outline). Dorsal hinge straight; the anterior cardinal spine could reach up to $8 \mathrm{~mm}$, with a maximum thickness $c a .2 .2 \mathrm{~mm}$ at the base. The posterior one is almost the same length with the anterior cardinal spine, with a maximum thickness $c a$. $1.8 \mathrm{~mm}$ at the base. Anterior ventral margin vaulted forward to some degree. The angle between the anterior spine axis and anterior margin (ada) is $74^{\circ}-76^{\circ}$, and the angle between the posterior spine axis and posterior margin (pda) is $78^{\circ}-80^{\circ}$. Some specimens present a doublure around the ventral margin. Carapace smooth. 

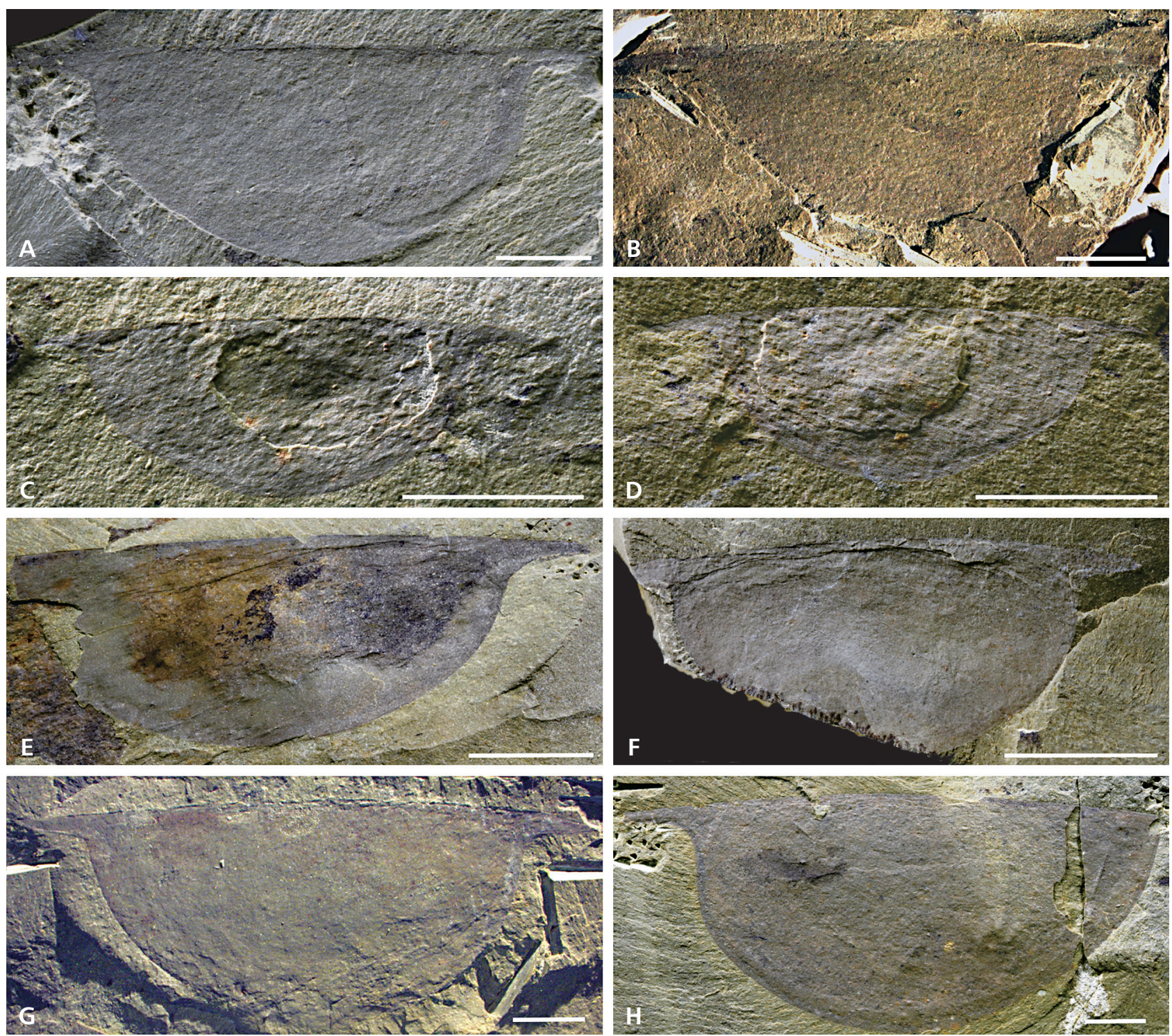

Figure 4. Isoxys auritus (Jiang, 1982), Lazizhai section, Balang Formation (Cambrian Stage 4) near Lazizhai Village, Jianhe County, Guizhou Province, China. A - complete left valve, lateral view, JLS170-537; B - nearly complete right valve with straight dorsal line, JLS170-614; C - complete right valve with asymmetric long acs and pcs, JLS77-6a; D - counterpart of C., JLS77-6b; E - complete right valve with more swollen anterior margin and small, short pcs, JLS170-989; F - incomplete right valve with part of postero-ventral missing, JLS160-134; G - complete right valve with obviously doublure, JLS160-2967; H - nearly complete left valve with strong and narrow ventral doublure, JLS85-110. Scale bars represent $5 \mathrm{~mm}$.

Remarks. - Until now, I. auritus only occurred in the Chengjiang Biota. The new specimens from the Balang Fauna resemble the previously described materials from the Chengjiang Biota (e.g. Hou et al. 2003, Fu et al. 2011). The length of the valve exceeds $50 \mathrm{~mm}$ in some cases (excluding cardinal spines). These individuals are larger than those of the Chengiiang Biota. Disparities in individual sizes are probably attributable to the differing ecological factors of the localities. Because the Balang Formation was deposited in the relatively deep water of the outer shelf as compared with the Heilinpu Formation (Chengjiang
Biota), which was deposited in relatively shallow shelf environments (see Hou et al. 1999) or possibly because of ontogenetic age differences in the examined specimens (Fu et al. 2011), the ontogenetic morphology features of the carapace of $I$. auritus from the Balang Fauna belong to the preadult and adults stage, and there is a lack of fine lines or fine reticulation ornaments on the carapace. However, such ornament features are common among those of the Chengjiang Biota; perhaps these differences can be considered as sexual dimorphs (Fu et al. 2014). It is possible that the differences result in taphonomic bias. 
Since the surfaces of the valves of the specimens from the Balang Fauna obviously lack sharpness, they are not comparable with those of the Chengjiang Biota.

Occurrence. - Kunming City, Yunnan Province, South China, the Maotianshan Shale of the Yu'anshan Member of the Helinpu Formation (previously Qiongzhusi Formation) (Cambrian Stage 3); Lazizhai Village, Jianhe County, Guizhou Province, South China, the Balang Formation (Cambrian Stage 4).

\section{Isoxys globulus sp. nov.}

Figure 5

Holotype. - Complete left valve with both anterior and posterior spines. Length: $18.33 \mathrm{~mm}$ (excluding cardinal spines), height: $12.1 \mathrm{~mm}$ (JLS85-99) (Fig. 5C).

Paratypes. - Paratype 1: Incomplete left valve showing anterior ventral margin and anterior cardinal spine; height: $21.88 \mathrm{~mm}$ (JLS77-85) (Fig. 5D). Paratype 2: Incomplete left valve showing posterior ventral margin and posterior cardinal spine; height: $25.21 \mathrm{~mm}$ (JLS78-3) (Fig. 5G).

Type horizon and locality. - Stage 4, Series 2 of Cambrian, Lazizhai Village, Jianhe County, Guizhou Province, South China.

Material. -25 specimens; 1 complete, 4 almost complete and the other 20 incomplete with partial valves.

Etymology. - Derived from the Latin globulus, rounded.

Diagnosis. - Valve large, ventral outline nearly semicircle, slightly wider anteriorly, dorsal line straight, subequal lengths of acs and pcs. Greatest height close to mid-length (amplete outline); angle between anterior spine axis and anterior margin (ada) $90^{\circ}-110^{\circ}$, and later one between posterior spine axis and posterior margin (pda) $100^{\circ}-110^{\circ}$. Valve L:H ratio: 1.55-1.69. Both anterior and posterior ventral margins rounded; anterior margin more swollen; carapace surface is smooth.

Description. - Ventral outline nearly round, wider anteriorly, length ranges from 13.44 to $56.54 \mathrm{~mm}$ (excluding cardinal spines), and height from 7.93 to $33.45 \mathrm{~mm}$; L:H ratio from 1.55 to 1.69 . Dorsal line straight, lengths of acp and pcp subequal; however, lengths of the cardinal spines in both juvenile and adult stages vary from $31.3 \%$ to $19.6 \%$ of the total length, taking the length of the shield, ada $90^{\circ}-110^{\circ}$, pda $100^{\circ}-110^{\circ}$; anterior cardinal spine $c a .6-10 \mathrm{~mm}$ long, while posterior one varies from 5.5 to $10 \mathrm{~mm}$ in length. Over the ontogenetic stages, the position of greatest height changes from close to mid-length (amplete outline) to the anterior ventral margin (preplete outline). Anterior and posterior cardinal spines range from slender, short to thick and long, and broad at the base. The anterior ventral margin is vaulted more obviously than the posterior ventral margin. Carapace smooth.

Remarks. - I. globulus differs from all congeneric species through the characteristics of a bloated body and no lineated nor reticulated micro-ornaments. Meanwhile, acs and pcs are subequal in length, but both have a thick, broad base, which differs from I. auritus. I. globulus is, so far, the species displaying the largest valves, with a length of $56.54 \mathrm{~mm}$ (excluding cardinal spines) and a height of $33.45 \mathrm{~mm}$. The features of the new species - a more rounded anterior ventral margin, smooth carapace without ornaments, anterior and posterior ventral margins nearly symmetrical, and larger-sized individuals - are clearly distinguished from those of other species of Isoxys.

Occurrence. - Lazizhai Village, Jianhe County, Guizhou Province, South China, the Balang Formation (Cambrian Stage 4).

\section{Isoxys jianheensis sp. nov. Figure 6}

Holotype. - Right-valve with part and counterpart; length: $17.65 \mathrm{~mm}$, height: $11.47 \mathrm{~mm}$ (JLS170-2030a, b) (Fig. 6A, B).

Paratypes. - Paratype 1: Complete right valve showing clear posterior cardinal spine; length: $18.53 \mathrm{~mm}$, height: $11.51 \mathrm{~mm}$ (JLS170-670) (Fig. 6C). Paraty pe 2: Carapace preserved in "butterfly" position. Dorsal view shows lateral ridge and obviously broad marginal doublure. Length: $18 \mathrm{~mm}$, height: 9 mm (JLS160-141) (Fig. 6G).

Type horizon and locality. - Stage 4, Series 2 of Cambrian, Lazizhai Village, Jianhe County, Guizhou Province, South China.

Material. - 28 specimens; 3 complete, 3 almost complete, and 19 incomplete with partial valves.

Etymology. - From the name of Jianhe, Guizhou, China, where the Balang Fauna is located.

Diagnosis. - Valve medium sized, semi-oval in outline, subequally wide anteriorly and posteriorly and straight dorsal line. Maximum valve height located at mid-length (amplete outline). Valves armed with a droopy and broadbased anterior cardinal spine; posterior pine small, short, and pointing slightly upward. Ventral margin shows a broad doublure. Short lateral ridge located in the lower-middle part of the valve, forming a short line that does not reach the ventral margin toward the posterior ventral oblique 

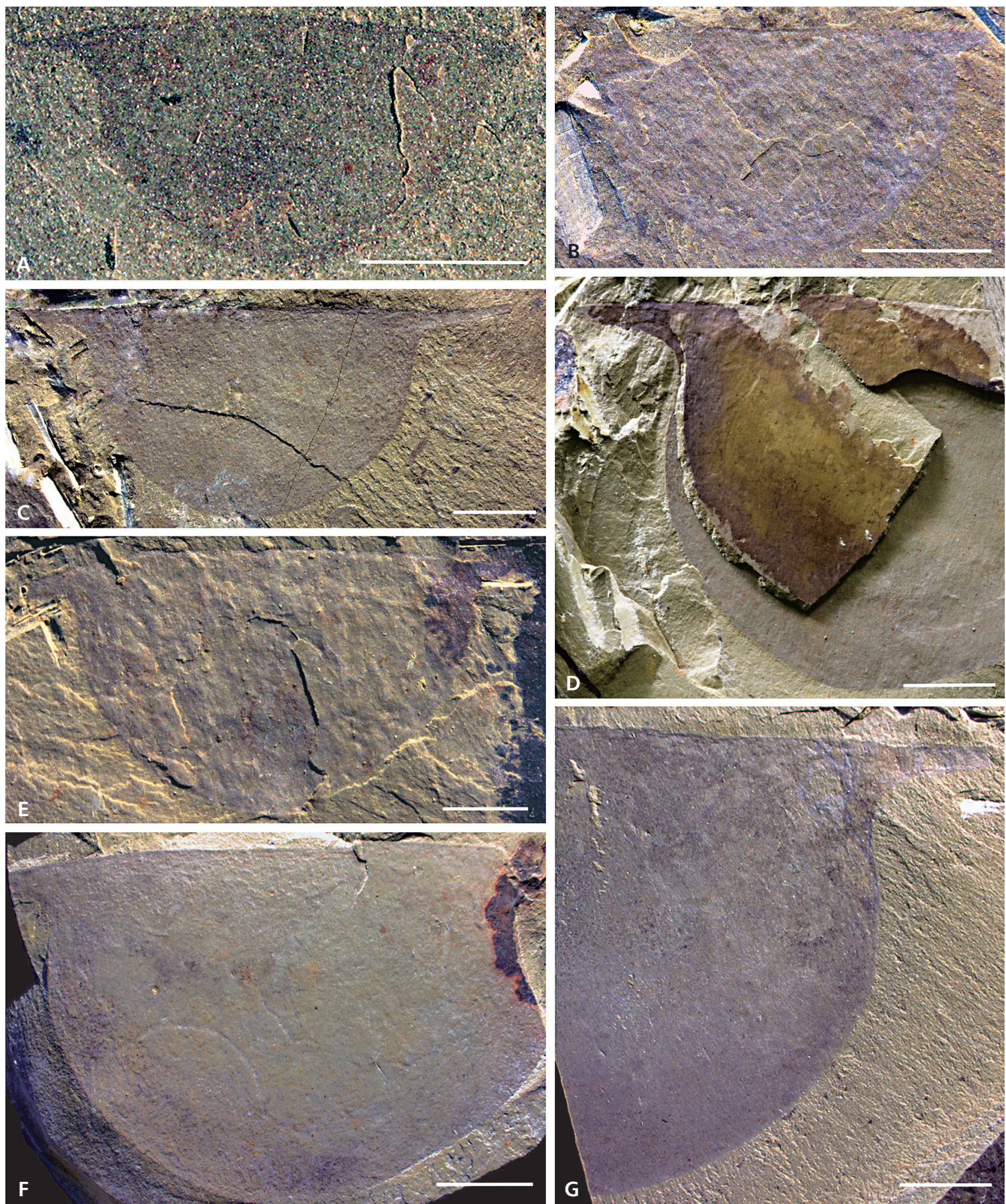

Figure 5. Isoxys globulus sp. nov., Lazizhai section, Balang Formation (Cambrian Stage 4) near Lazizhai Village, Jianhe County, Guizhou Province, China. A - juvenile left valve with a thick and pointed acs, JLS170-1704; B - incomplete right valve, JLS160-558; C - complete left valve, with ventral margin and asymmetric long acs and pcs in the dorsal line, holotype, JLS85-99; D - incomplete left valve with strong acs and enlarged anterior ventral margin, JLS77-85; E - nearly complete left valve with amplete outline, JLS85-773; F - incomplete left valve lacking cardinal spines, and line-like trace fossils on the valve surface, JLS85-193; G - incomplete left valve with posterior ventral margin and pcs, JLS78-3. Scale bars represent $5 \mathrm{~mm}$. 

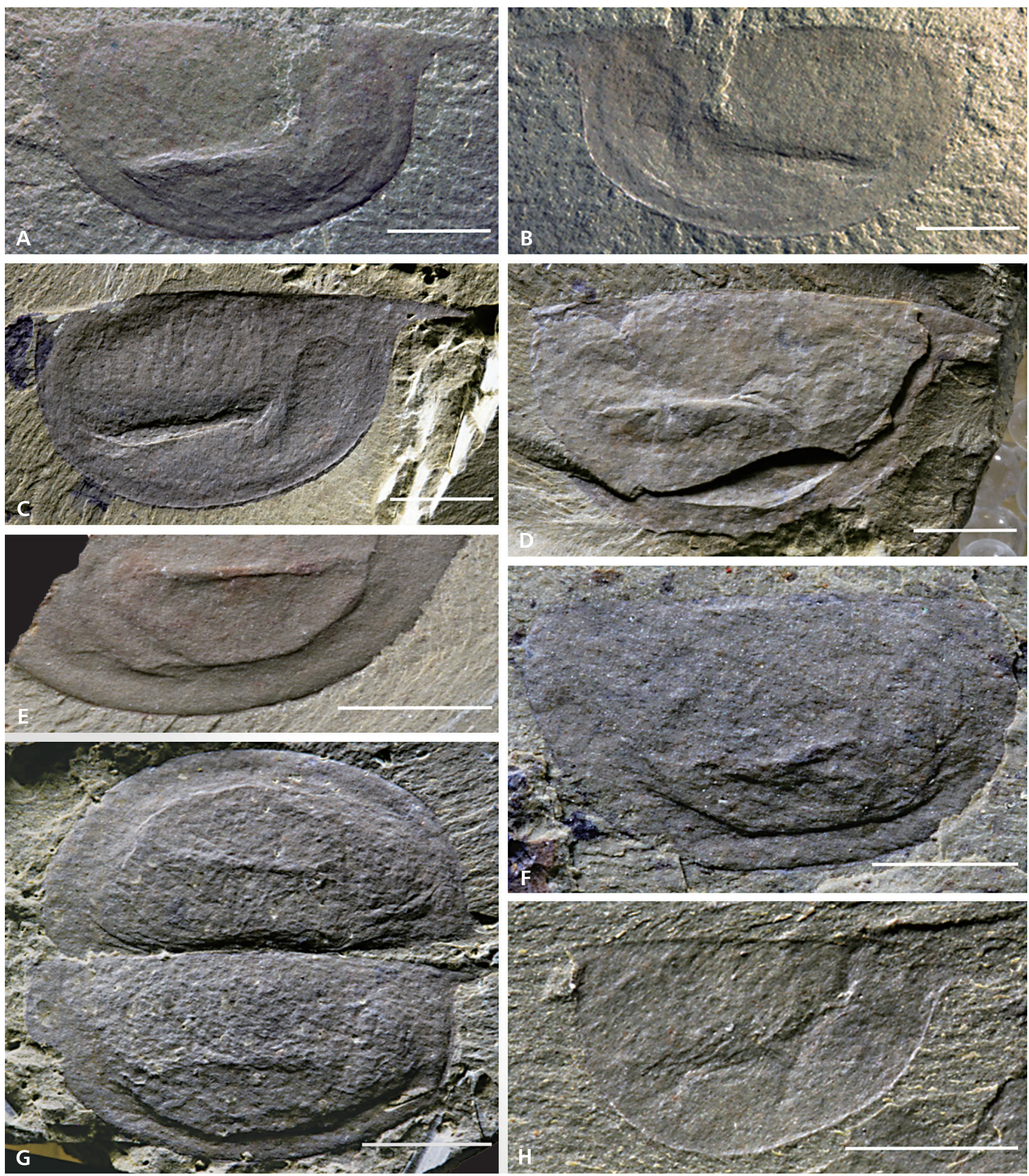

Figure 6. Isoxys jianheensis sp. nov., Lazizhai section, Balang Formation (Cambrian Stage 4) near Lazizhai Village, Jianhe County, Guizhou Province, China. A, B - part and counterpart of completely preserved right valve, with lateral ridge, broad marginal doublure and microornament on the surface of the valve, holotype, JLS170-2030a, b; C - complete right valve with strong acs and minor pcs, lateral ridge and microornament can be seen on the valve, paratype 1, JLS170-670; D -complete right valve with a thick shell, partial layer falling off in the mid- to posterior area of the ventral margin, lateral ridge, and asymmetrical cardinal spines, JLS160-260; E - incomplete ventral part with clear lateral ridge and compression lines as well as broad marginal doublure, JLS160-249; F - incomplete right valve lacking cardinal spines with clear lateral ridge and compression lines, JLS160-117; G - specimen in "butterfly" position, dorsal view with lateral ridge, broad marginal doublure, lacks acs and pcs, paratype 2, JLS160-141; H - juvenile right valve, with minute posterior cardinal spine and postplete outline, JLS160-886. Scale bars represent $5 \mathrm{~mm}$. 

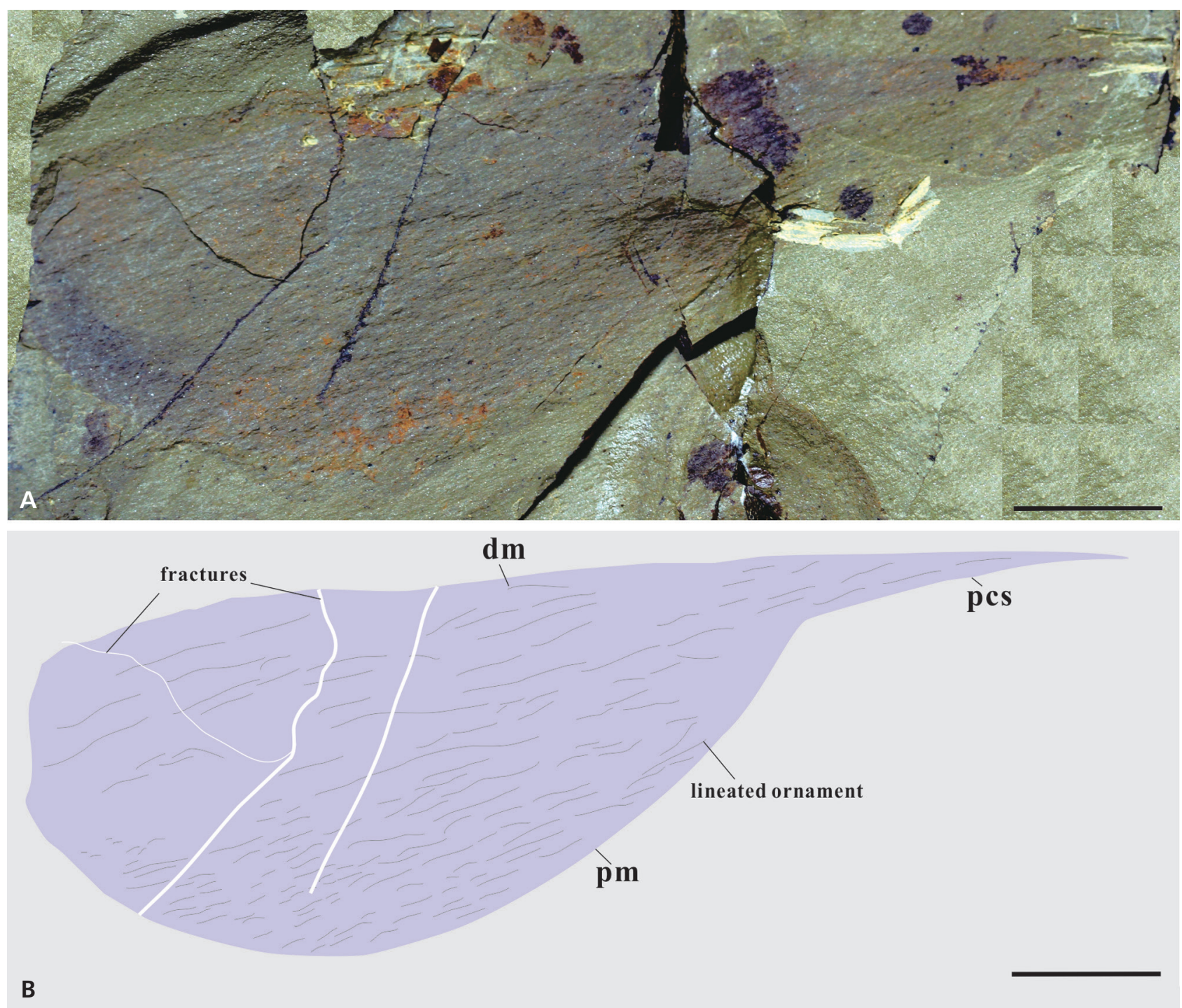

Figure 7. Isoxys sp., Lazizhai section, Balang Formation (Cambrian Stage 4) near Lazizhai Village, Jianhe County, Guizhou Province, China. A - incomplete left valve without anterior spine, posterior spine long and sharp, JLS170-1160; B - interpretative drawing of A. Scale bar represents $10 \mathrm{~mm}$.

stretch. Position of the lateral ridge is located at the point of the valve vaulting. Faint microreticulated ornaments formed by adjacent hexagons on surface of valve.

Description. - Valve medium sized, semi oval outline, wide anterior ventral, almost equal posterior one. Length: $14.2-36.33 \mathrm{~mm}$ (excluding cardinal spines); height: 9.73-23.14 mm; L:H: 1.46-1.57. Dorsal margin nearly straight with gentle, dorsally directed flexure about onethird of the way from the anterior end. Anterior cardinal spine ranges from 3.0 to $6.0 \mathrm{~mm}$ in length, posterior one from 0.5 to $3.0 \mathrm{~mm}$. Angle between the anterior spine axis and the anterior margin (ada) between $100^{\circ}$ and $115^{\circ}$, and the pda between $120^{\circ}$ and $135^{\circ}$. Surface of the valve covered by a microreticulated pattern. Reticulation varies, with a general diameter of about $1.4 \mathrm{~mm}$. The reticulate pattern is ill-defined or obliterated on some specimens. Short lateral ridge in the lower-middle part of the valve forms a short line that does not reach the ventral margin toward the posterior ventral oblique stretch; lateral ridge located at the point of the valve vaulting.

Remarks. - The new species closely resembles I. auritus. Their similarities include the semi-oval outline, marginal doublure, microreticulate pattern, and similar ratio of valve length and height. However, the front broad ventral marginal doublure, the almost symmetrical anterior and posterior ventral, and the lateral ridge can distinguish from the latter. Especially, the characteristic of the lateral ridge in the new species is completely distinct from all species 


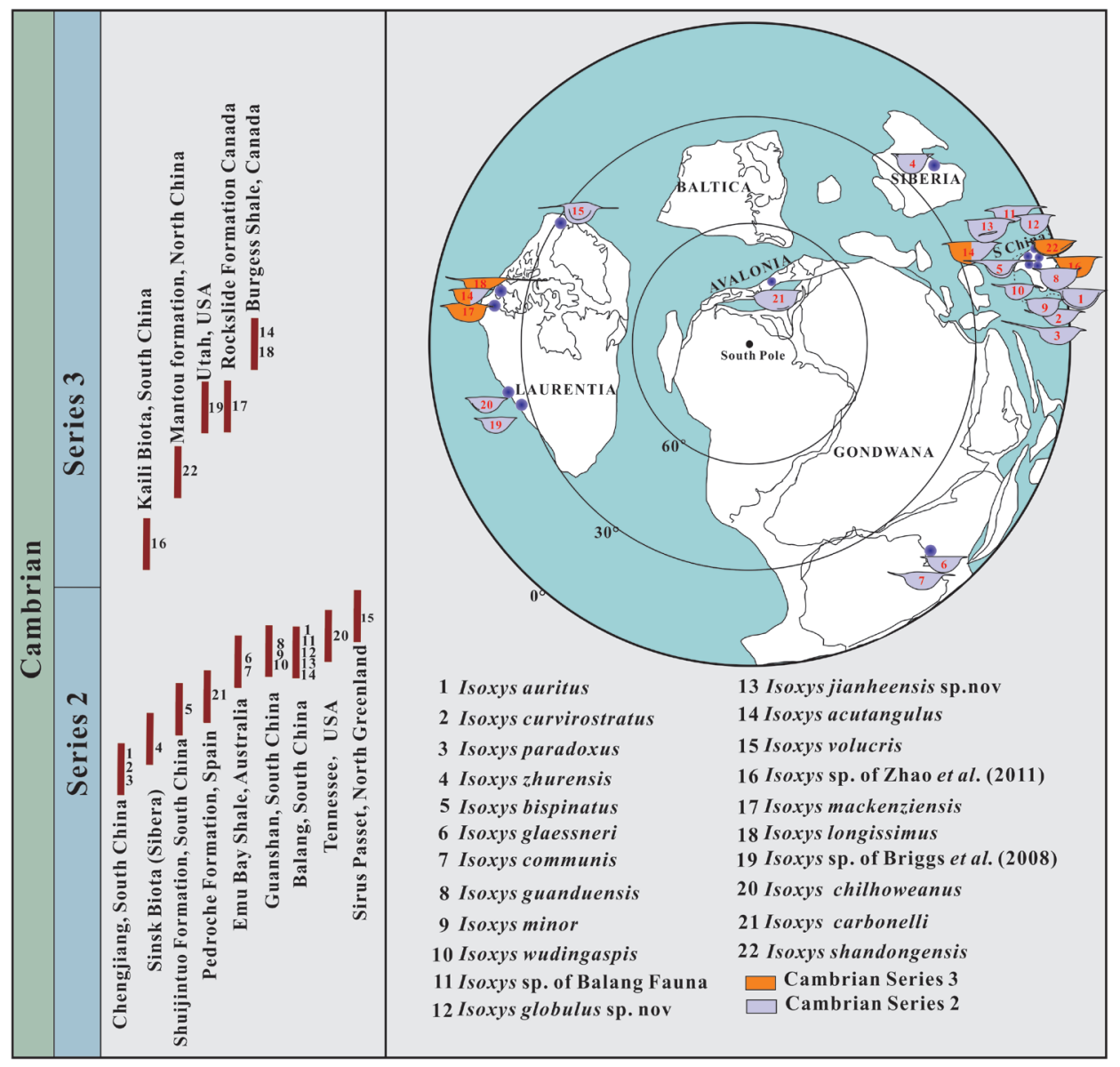

Figure 8. Global stratigraphic range of biotas containing Isoxys, Cambrian. Palaeogeographic distribution of all species of Isoxys; each taxon indicated by sequence number, corresponding to those beside the biotas. Map after McKerrow et al. (1992) and Cocks \& Torsvik (2002)

of Isoxys. These valve features resemble the structure of Tuzoia. However, Tuzoia has relatively short anterior and posterior cardinal processes, marginal spines, lateral ridge long and straight located at mid-height to reach marginal spines on the poster ventral; its valve surface is covered by a reticulate pattern of fine ridges with small meshwork, including anterior and posterior cardinal processes, dorsal line, and even lateral ridge positions on each valve. The new species do the microfine on valve surface, the lack of marginal spines, and the short and slightly oblique lateral ridge, which can be clearly distinguishing from those of Tuzoia. Thus, I. jianheensis sp. nov. should be a species of Isoxys with a lateral ridge, belonging to a new taxon.

Occurrence. - Lazizhai Village, Jianhe County, Guizhou Province, South China, Balang Formation (Cambrian Stage 4).

\section{Isoxys sp.}

Figure 7

Material. - One specimen incompletely preserved (JLS170-1160).
Diagnosis. - Valves large, elongated, near elliptical, broad anteriorly, straight dorsal line, greatest height before the mid-length of the valve, long posterior cardinal spine.

Description. - Incomplete specimen: left valve, nearly elliptical, broad anteriorly, straight dorsal line, greatest height before mid-length. Length: $43 \mathrm{~mm}$ (excluding cardinal spines), and height: $26 \mathrm{~mm}$. The carapace is large, with a long, straight posterior cardinal spine, more than $21 \mathrm{~mm}$ fully extended. Anterior cardinal spine (acs) missing, so the total length of the valve exceeds $70 \mathrm{~mm}$ (only including posterior cardinal spines). Carapace shows micro-lineated ornament, perhaps caused by compaction.

Remarks. - Isoxys sp. and I. paradoxus have similar outlines, all with huge and long pcs. However, the length of the posterior cardinal spine of I. paradoxus is greater than that of the carapace, and the pcs length of $I$. sp. is only half the length of the valve, although acs information for $I$. sp. is unknown. I. sp. also differs from I. longissimus with its relatively short pcs; the length of the posterior cardinal spine of I. longissimus exceeds the length of the valve. 
Thus, $I$. sp. can be easily distinguished from other species by its huge, and its possible microlined ornament.

Occurrence. - Lazizhai Village, Jianhe County, Guizhou Province, South China, the Balang Formation (Cambrian Stage 4).

\section{Discussion on stratigraphic range of Isoxys and its palaeogeographic distribution}

Isoxys is a cosmopolitan genus. Its special morphological characteristics, including the features of its soft body parts, such as the uniformous series of exopodal paddles fringed with long setae and the relative reduction of the endopodal rami (Vannier \& Chen 2000), and its wide distribution in the continental shelf, as well as in deep-water slope areas, suggest that it should be a swimming animal with dispersal capabilities similar to modern pelagic organisms (Williams et al. 1996, Vannier \& Chen 2000, Vannier et al. 2009, Huang \& Wang 2015). Based on palaeomagnetic data (McKerrow et al. 1992, Cocks \& Torsvik 2002), all species of this genus reported occur in a range between $30^{\circ} \mathrm{N}$ and $30^{\circ} \mathrm{S}$ (Williams et al. 1996). Therefore, they are absent from the higher-latitude areas of the southern hemisphere, such as Baltica, Avalonia, and South America, which hints at some temperature control. Some species may have strong dispersal capabilities, such as I. acutangulus while others belong to endemic forms (see Fig. 8). The specimens from the Balang Fauna bring new data which provide a better understanding of palaeogeograpical distribution of Isoxys. Isoxys group from the Balang Fauna shares one taxon with the Chengjiang Biota (Cambrian Stage 3) and the Burgess Shale Biota (Cambrian Stage 5) respectively, the Balang Formation represents primarily fine-grained siliciclastic sedimentation of the Transitional Slope Belt between the shallow Yangtze (or South China) Platform and the Jiangnan Basin. Here, remains of Isoxys are preserved in deeper water deposits beyond the shelf margin. Globally, most other occurrences of the genus are in shallow-shelf to deep-shelf deposits. The remains are parautochthonous (Liu et al. 2017), they occurrence in the Balang Formation extends our knowledge of the geographic occurrence and paleoecology of this arthropod.

\section{Conclusion}

Isoxys is a large bivalved arthropod with uncertain affinity that is well represented in strata of global Cambrian Series 2-3. The wide distribution of this group is possibly indicative of a swimming style. Assemblage of Isoxys described herein from the Balang Formation, Lazizhai Village, Jianhe County, Guizhou Province, China, includes five species: Isoxys acutangulus (Walcott, 1908), I. auritus (Jiang 1982), I. jianheensis sp. nov., I. globulus sp. nov., and Isoxys sp., which shares one taxon with the Chengjiang Biota (Cambrian Stage 3) and one with the Burgess Shale Biota (Cambrian Stage 5) and provides new essential information to a better understanding of the evolutionary pattern of these taxa in timeline, in terms of geographic distribution. The Isoxys species from the Balang Fauna are comparable with that of the equivalent Guanshan Biota. Observations of new taxa from the Balang Fauna open a new stratigraphic window on the diversity and early evolutionary history of this genus.

\section{Acknowledgements}

A special acknowledgment is given to Sun Haijing (State Key Laboratory of Palaeobiology and Stratigraphy, Nanjing Institute of Geology and Palaeontology, Chinese Academy of Sciences, 210008 Nanjing, China) for good revision and English correction in manuscript. Moreover, we thank reviewers V. Perrier and D. Legg for their constructive and helpful comments to help greatly improving the manuscript. This research was supported partly by grants from the National Sciences Foundation of China (No. 40672005; 41172005; 41222013), the Major State Basic Research Development Programme of China (973 Programme) (No. 2013CB835002; 2015FY310100-5), Guizhou Science and Technology Department of China (Gui, Sci. Z. [2014] 4003; Gui. Sci. R. C. [2017]5788) and Science and Research of Postgraduate from Guizhou, China (KYJJ2017003).

\section{References}

Bergeron, J. 1899. Etude de quelques trilobites de Chine. Bulletin de la Société Géologie de France 27, 499-516.

Bergström, J., Hou, X.G., Zhang, X.G. \& Clausen, S. 2008. A new view of the Cambrian arthropod Fuxianhuia. GFF 130, 189-201. DOI 10.1080/11035890809452772

Blaker, M.R. \& PeEL, J.S. 1997. Lower Cambrian trilobites from north Greenland. Meddelelser om Grønland, Geoscience 35, $1-145$.

Briggs, D.E.G., Erwin, D.H. \& Collier, F.J. 1994. The Fossils of the Burgess Shale. 238 pp. Smithsonian Institution Press, Washington.

Briggs, D.E.G., Lieberman, B.S., Hendricks, J.R., Halgedahl, S.L. \& JARRARD, R.D. 2008. Middle Cambrian arthropods from Utah. Journal of Paleontology 82(2), 238-254.

DOI 10.1666/06-086.1

Butterfield, N.J. \& Nicholas, C.J. 1994. Exceptionally preserved fossils from the Lower-Middle Cambrian Mount Cap Formation, Northwest Territories, Canada. Palaeontology Newsletter 24, 16.

Campbell, L. \& Kauffman, M.E. 1969. Olenellus fauna of the 
Kinzers Formation, Southeastern Pennsylvania. Proceedings of the Pennsylvania Academy of Science 43, 172-176.

Chen, J.Y. 1996. Witness to fossils, 64-104. In Chen, J.Y., ZHou, G.Q., ZHu, M.Y. \&Ye, G.Y. (eds) Chengjiang biota-witness of the Cambrian explosion. Taiwan: national museum of natural science press.

CHen, J.Y. 2004. The dawn of animal world. 251-256. In CHEN, J.Y. (ed.) Treatise on Arthropoda, Part Isoxys. Jiangsu science and technology press, Nanjing. [in Chinese]

Chen, J.Y. \& Zhou, G.Q. 1997. Biology of the Chengjiang Fauna. Bulletin of the National Museum of Natural Science 10, 1-106.

Chien (QIan), Y.Y. 1961. Cambrian trilobites from San-du and Duyun, southern Kweichou. Acta Palaeontologica Sinica, 9(2), 91-129. [in Chinese with English summary]

Cocks, L.R.M. \& Torsvik, T.H. 2002. Earth geography from 500 to 400 million years ago: a faunal and palaeomagnetic review. Journal of the Geological Society 159(6), 631-644. DOI 10.1144/0016-764901-118

Collins, D.H. 1986. Paradise Revisited. Rotunda 19, 30-39.

Conway Morris, C., Peel, J.S., Higgins, A.K., Soper, N.J. \& DAvis, N.C.D. 1987. A Burgess Shale-like fauna from the Lower Cambrian of North Greenland. Nature 326, 181-183. DOI 10.1038/326181a0

Daily, B. 1956. The Cambrian in South Australia. 1-30. In Rodgers, J. (ed.) El Sistema Cambrico, su paleogeografia y el problema de su base.

Delle Cave, D.L. \& Simonetta, A.M. 1991. Early Palaeozoic arthropods and problems of arthropod phylogeny; with some notes on taxa of doubtful affinities. 189-244. In SimonetTA, A.M. \& Conway Morris, S. (eds) The Early Evolution of the Metazoa and the Significance of Problematic Taxa. Cambridge University Press, Cambridge.

Donovan, S.K. \& Lewis, D.N. 2001. Fossils explained. 38. The Burgess Shale biota. Geology Today 17, 231-235.

DOI 10.1046/j.0266-6979. 2001.00314.x

Fletcher, T.P. \& Collins, D.H. 1998. The Middle Cambrian Burgess Shale and its relationship to the Stephen Formation in the southern Canadian Rocky Mountains. Canadian Journal of Earth Sciences 35, 413-436. DOI 10.1139/cjes-35-4-413

Fu, D.J., Zhang, X.L., Budd, G.E., Liu, W. \& PAN, X.Y. 2014. Ontogeny and dimorphism of Isoxys auritus (Arthropoda) from the Early Cambrian Chengjiang biota, South China. Gondwana Research 25, 975-982. DOI 10.1016/j.gr.2013.06.007

Fu, D.J., Zhang, X.L. \& Shu, D.G. 2011. Soft anatomy of the Early Cambrian arthropod Isoxys curvirostratus from the Chengjiang biota of South China with a discussion on the origination of great appendages. Acta Palaeontologica Polonica 56(4), 843-852. DOI 10.4202/app.2010.0090

García-Bellido, D.C., Paterson, J.R., Edgecombe, G.D., Jago, J.B., Gehling, J.G. \& Lee, M.S.Y. 2009a. The bivalved arthropods Isoxys and Tuzoia with soft-part preservation from the Lower Cambrian Emu Bay Shale Lagerstätte (Kangaroo Island, Australia). Palaeontology 52(6), 1221-1241.

DOI 10.1111/j.1475-4983.2009.00914.x
García-Bellido, D.C., Vannier, J. \& Collins, D. 2009b. Soft-part preservation in two species of the arthropod Isoxys from the middle Cambrian Burgess Shale of British Columbia, Canada. Acta Palaeontologica Polonica 54(4), 699-712.

DOI 10.4202/app.2009.0024

Glaessner, M.F. 1979. Lower Cambrian Crustacea and annelid worms from Kangaroo Island, South Australia. Alcheringa 3(1), 21-31. DOI 10.1080/03115517908565437

Hou, X.G. 1987. Early Cambrian large bivalved Arthropoda from Chengjiang, Eastern Yunnan. Acta Palaeontologica Sinica 26(3), 286-298. [in Chinese with English abstract]

Hou, X.G., Aldridge, R.J., Bergström, J., Siveter, D.J. \& Feng, X.H. 2003. The Cambrian Fossils of Chengjiang, China, the flowering of Early animal life. 233 pp. Blackwell Science Ltd., Bath.

Hou, X.G., Bergström, J., Wang, H.F., Feng, X.H. \& Chen, A.L. 1999. The Chengjiang Fauna exceptionally well-preservad animals from 530 million years ago. 170 pp. Yunnan science and technology press, Kunming. [in Chinese]

Hu, S.X., Li, Y., Luo, H.L., Fu, X.P., You, T., Pang, J.Y., Liu, Q. \& Sterner, M. 2008. New Record of Palaeoscolecids from the Early Cambrian of Yunnan, China. Acta Geologica Sinica, 82(2), 244-248.

HuAng, D.Y. \& WAnG, Y.N. 2015. The soft anatomy of Isoxys minor from the Guanshan fauna, lower Cambrian of Southwest China. Palaeoworld 23, 225-228.

DOI 10.1016/j.palwor.2014.10.006

Ivantsov, A.I. 1990. Pervye hakhodki fillokarid v nizhnem kembrii Iakutii. Palaeontologičeskij Žurnal 34, 130-132. [in Russian]

Ivantsov, A.I. 2005. Tardipolypodians, 112-113. In PonoMarenko, A.G. (ed.) Unique Sinsk Localities of Early Cambrian Organisms (Siberian Platform). Nauka, Moscow. [in Russian]

JiANG, Z.W. 1982. Small shelly fossils, 163-199. In Luo, H.L., JiAng, Z.W., Wu, X.C., Song, X.L. \& OuYang, L. (eds) The SinianCambrian Boundary in Eastern Yunnan China. People's Publishing House of Yunnan, Kunming. [in Chinese]

LegG, D.A. \& CARON, J.B. 2014. New middle Cambrian bivalved arthropods from the Burgess Shale (British Columbia, Canada). Palaeontology 57(4), 691-711. DOI 10.1111/pala.12081

LEgG, D.A. \& VAnNiER, J. 2013. The affinities of the cosmopolitan arthropod Isoxys and its implications for the origin of arthropods. Lethaia 46(4), 540-550. DOI 10.1111/let.12032

LegG, D.A., Sutton, M.D., Edgecombe, G.D. \& Caron, J.B. 2012. Cambrian bivalved arthropod reveals origin of arthrodization. Proceedings of the Royal Society of London B: Biological Sciences 279, 4699-4704. DOI 10.1098/rspb.2012.1958

LiU, Q. \& LeI, Q.P. 2013. Discovery of an exceptionally preserved fossil assemblage in the Balang Formation (Cambrian Series 2, Stage 4) in Hunan, China. Alcheringa 37(2), 269-271.

DOI 10.1080/03115518.2013.764663

Liu, S., Wen, R.Q., Peng, J., Liang, B.Y. \& Wang, Q.J. 2017. A preliminary study on taphonomy of the Balang Lagerstätte 
from the Cambrian (Stage 4), Balang Formation at Jianhe, Guizhou, China-Example for Lazizhai section of the Balang Formation. Acta Palaeontologica Sinica 56(3), 282-230. [in Chinese with English summary]

Lu, Y.H., Zhang, W.T., Qian, Y.Y., Zhu, Z.L., Lin, H.L., Zhou, Z.Y., Qian, Y., Zhang, S.G. \& Wu, H.J. 1974. The Cambrian trilobite. Handbook of Stratigraphy and Palaeontology of South China. 82-107 pp. Science Press, Beijing. [in Chinese]

Luo, H.L. 1994. On the biogeographical division of Cambrian in east Yunnan. Acta Palaeontologica Sinica 13(3), 233-239. [in Chinese with English summary]

Luo, H.L., Hu, S.X., Chen, L.Z., Zhang, S.S., TaO, Y.H. 1999. Early Cambrian Chengjiang Fauna from Kunming region. 129 pp. Yunnan Science of Technology Press, Kunming. [in Chinese with English summary]

Luo, H.L., Fu, X.P., Hu, S.X., Li, Y., Chen, Z.L., You, T. \& Liu, Q. 2006. New bivalved Arthropods from the Early Cambrian Guanshan Fauna in the Kunming and Wuding area. Acta Palaeontologica Sinica 45, 460-472. [in Chinese with English summary]

Luo, H.L., Fu, X.P., Hu, S.X., Li, Y., Chen, Z.L., You, T. \& Liu, Q. 2008. Early Cambrian large bivalved Arthropods from Chengjiang. Acta Palaeontologica Sinica 45(4), 460-472.

Ma, H.T., Peng, J., Zhao, Y.L., DA, Y. \& Sun, H.J. 2011. Discovery of the Balang Fauna at Luojiatang, Yangqiao, Cengong, Guizhou and its significance to the early evolution of the Metazoa. Geological Review 57, 743-748. [in Chinese with English summary]

McKerrow, W.S., Scotese, C.R. \& Brasier, M.D. 1992. Early Cambrian continental reconstructions. Journal of the Geological Society 149(4), 599-606.

DOI 10.1144/gsjgs.149.4.0599

Nedin, C. 1995. The Emu Bay Shale, a Lower Cambrian fossil Lagerstätte, Kangaroo Island, South Australia. Association of Palaeontologists Memoir 18, 31-40.

ÖPIK, A.A. 1970. Redlichia of the Ordian (Cambrian of northern Australia and New South Wales). Bulletin of Bureau of Mineral Resources. Geology and Geophysics 114, 1-66.

PAN, J. 1957. On the discovery of Homopoda from South China. Palaeontologica Sinica 5, 523-526. [in Chinese with English abstract]

Peel, J.S. 2010. Articulated hyoliths and other fossils from the Sirius Passet Lagerstätte (early Cambrian) of North Greenland. Bulletin of Geosciences 85(3), 385-394.

DOI 10.3140/bull.geosci.1207

Peng, J. 2009. The Qiandongian (Cambrian) Balang Fauna from Eastern Guizhou, South China. 137 pp. Ph.D. thesis, Nanjing University, Nanjing, China.

Peng, S.C. \& BABCock, L.E. 2001. Cambrian of the HunanGuizhou region, South China, 3-51. In PeNG, S.C., BABCOCK, L.E. \& ZHU, M.Y. (eds) Cambrian System of South China. Palaeoworld 13.

Peng, J., Feng, H.Z., Fu, X.P., ZhaO, Y.L. \& Yao, L. 2010. New bradoriid arthropods from the Qiandongian (Lower Cambrian)
Balang Formation, eastern Guizhou, South China. Bulletin of Geosciences 84(1), 143-150.

Peng, J., Huang, D., Zhao, Y.L. \& Sun, H. 2016. Palaeoscolecids from the Balang Fauna of the Qiandongian (Cambrian series 2), Guizhou, China. Geological Magazine 153(3), 438-448. DOI 10.1017/S0016756815000205

Peng, J., Sun, H.J, Zhao, Y.L. \& TaI, T.S. 2012b. The Jiaobang Section: The Balang Formation and the Balang Fauna (Cambrian Series 2 Stage 4) near Jiaobang village, Jianhe County, Guizhou Province, China, 125-132. In ZHAO, Y.L., Zhu, M.Y., Peng, J., Gaines, R.R. \& Parsley, R.L. (eds) Cryogenian-Ediacaran to Cambrian Stratigraphy and Paleontology of Guizhou. Guizhou University Press, Guiyang.

Peng, J., Sun, H.J, Zhao, Y.L. \& Yan, Q.J. 2012a. The fossil Geyi section of Balang Formation (Cambrian Series 2, Stage 4) near Taijiang County, Guizhou Province, South China. 89-97. In Zhao, Y.L., Zhu, M.Y., Peng, J., Gaines, R.R. \& Parsley, R.L. (eds) Cryogenian-Ediacaran to Cambrian Stratigraphy and Paleontology of Guizhou. Guizhou University Press, Guiyang.

Peng, J., Zhao, Y.L. \& Sun, H.J. 2012c. Discovery and significance of Naraoia from the Qiandongian (lower Cambrian) Balang Formation, Eastern Guizhou, South China. Bulletin of Geoscience 87(1), 143-150. DOI 10.3140/bull.geosci.1231

Peng, J., Zhao, Y.L., Wu, Y.S., Yuan, J.L. \& TaI, T.S. 2005. The Balang Fauna: a new early Cambrian Fauna from Kaili City, Guizhou Province. Chinese Science Bulletin 50(11), 1159-1162. DOI 10.1360/982005-183

QIn, Q., Peng, J., Fu, X.P. \& DA, Y. 2010. Restudy of Changaspis (Lee, 1961) from Qiandongian (Early Cambrian) Balang Formation near eastern Guizhou, south China. Acta Palaeontologica Sinica 49(2), 220-230. [in Chinese with English abstract]

Richter, R. \& Richter, E. 1927. Eine Crustacee (Isoxys carbonelii n. sp.) in den Archaeocyathus - Bildungen der Sierra Morena und ihre stratigraphische Beurteilung. Senckenbergiana 9, 188-195.

Schoenemann, B. \& Clarkson, E.N. 2011. Eyes and vision in the Chengjiang arthropod Isoxys indicating adaptation to habitat. Lethaia 44(2), 223-230. DOI 10.1111/j.1502-3931. 2010.00239.x

Shen, Z., Peng, J., Wen, R.Q. \& Liu, S. 2016. Arthricocephalites (Trilobite) from the Cambrian and its stratigraphic significance. Acta Palaeontologica Sinica 55(1), 9-18. [in Chinese with English abstract]

Shu, D.G., Zhang, X.L. \& Geyer, G. 1995. Anatomy and systematic affinities of the Lower Cambrian bivalved arthropod Isoxys auritus. Alcheringa 19(4), 333-342.

DOI 10.1080/03115519508619512

Siebold, C.T. von 1848. Lehrbuch der vergleichenden Anatomieder Wirbellosen Thiere. Erster Theil, 1-679. In Siebold, C.T. von \& Stanniu, S.H. (eds) Lehrbuch der vergleichenden Anatomie. Verlag von Veit \& Comp., Berlin. 
Simonetta, A.M. \& Delle Cave, L.D. 1975. The Cambrian non-trilobite arthropods from the Burgess Shale of British Columbia. A study of their comparative morphology, taxonomy and evolutionary significance. Palaeontographia Italica 69, 1-37.

Stein, M., Peel, J.S., Siveter, D.J. \& Williams, M. 2010. Isoxys (Arthropoda) with preserved soft anatomy from the Sirius Passet Lagerstätte, Lower Cambrian of North Greenland. Lethaia 43(2), 258-265.

DOI 10.1111/j.1502-3931. 2009.00189.x

Steiner, M., Zhu, M.Y., Zhao, Y.L. \& Erdtmann, B.D.E. 2005. Lower Cambrian Burgess Shale-type fossil associations of South China. Palaeogeography, Palaeoclimatology, Palaeoecology 220(1), 129-152.

DOI 10.1016/j.palaeo.2003.06.001

VANnIER, J. \& ChEn, J.Y. 2000. The Early Cambrian colonization of pelagic niches exemplified by Isoxys (Arthropoda). Lethaia 33(4), 295-311. DOI 10.1080/002411600750053862

Vannier, J., García-Bellido, D.C., Hu, S.X. \& Chen, A.L. 2009. Arthropod visual predators in the early pelagic ecosystem: evidence from the Burgess Shale and Chengjiang biotas. Proceedings of the Royal Society of London B: Biological Sciences 276, 2567-2574. DOI 10.1098/rspb.2009.0361

Vannier, J., Williams, M., Alvaro, J.J., Vizcaïno, D., Monceret, S. \& Monceret, E. 2005. New Early Cambrian bivalved arthropods from southern France. Geological Magazine 142(3), 751-763. DOI 10.1017/S0016756805001093

Walcott, C.D. 1890. The Fauna of the Lower Cambrian or Olenellus Zone. Reports of the U.S. Geological Survey 10, 509-763.

Walcott, C.D. 1905. Cambrian faunas of China. Proceedings of the United States National Museum 29(14150), 1-106. DOI 10.5479/si.00963801.1415

Walcott, C.D. 1908. Mount Stephen rocks and fossils. The Canadian Alpine Journal 1, 232-248.

Walcott, C.D. 1928. Cambrian geology and paleontology V. PreDevonian Paleozoic formations of the Cordilleran provinces of Canada. Smithsonian Miscellaneous Collections 75, 175-368.

Wang, Y.N., Huang, D.Y. \& Lieberman, B.S. 2010. New Isoxys (Arthropoda) from the Cambrian, Mantou Fromation, Shandong Province. Acta Palaeontologica Sinica 49(3), 398-406. [in Chinese with English abstract]

Wen, R.Q., Zhao, Y.L. \& Peng, J. 2015. Morphology and ontogeny of Tuzoia bispinosa from the Kaili Biota (Cambrian Stage 5) of eastern Guizhou, China. Palaeoworld 24(1), 61-70.

DOI 10.1016/j.palwor.2014.12.005

Williams, M., Siveter, D.J. \& Peel, J.S. 1996. Isoxys (Arthropoda) from the Early Cambrian Sirius Passet Lagerstätte, North Greenland. Journal of Paleontology 70(6), 947-954. DOI 10.1017/S0022336000038646

Yan, Q.J., Peng, J., Zhao, Y.L., Weng, R.Q. \& Sun, H.J. 2014. Restudy of sedimentary and stratigraphy of the Qiandongian (Cambrian) Balang Formation at Jianhe, Guizhou, China- example for Jiaobang section of the Balang Formation. Geological Review 60 (4), 893-902. [in Chinese with English abstract]

Yin, G.Z. 1987. Cambrian, 49-96. In Bureau of Guizhou Geology and Mineral Resources (ed.). Regional Geology of Guizhou Province. Beijing: Geological Publishing Press. P.R.C. Ministry of Geology and Mineral Resources: Geological Memories series 1, No.7. [in Chinese with English summary]

YIN, G.Z. 1996. Division and correlation of Cambrian in Guizhou. Guizhou Geology 13(2), 115-128. [in Chinese with English abstract]

Yuan, J.L., Zhao, Y.L. \& Li, Y. 2001. Biostratigraphy of oryctocephalid trilobites. Acta Palaeontologica Sinica 40(Supplement), 143-156. [in Chinese with English summary]

Yuan, J.L., Zhao, Y.L. \& YAnG, X.L. 2006. Speciation of the genus Arthricocephalus Bergeron, 1899 (Trilobita) from the late Early Cambrian and its stratigraphic significance. Progress in Natural Science 16(6), 614-623.

DOI 10.1080/10020070612330043

Yuan, J.L., Zhao, Y.L., Li, Y. \& Huang, Y.Z. 2002. Trilobite Fauna of Kaili Formation (Uppermost Lower Cambrian Middle Cambrian) from Southeastern Guizhou, South China. 423 pp. Shanghai Science and Technology Press, Shanghai. [in Chinese with English summary]

Zhao, Y.L., Parsley, R.L. \& Peng, J. 2007. Early Cambrian Eocrinoids from Guizhou Province, South China. Palaeogeography, Palaeoclimatology, Palaeoecology 254, 317-327. DOI 10.1016/j.palaeo.2007.03.020

Zhao, Y.L., Peng, J., Wu, M.Y., Luo, X.C., Wen, R.Q. \& Liu, Y.J. 2015. A new type of Echinoderms from Balang Formation in Cambrian from Xiaxi Town, Majiang County, Guizhou, China. Earth Science, Journal of China University of Geoscience 40(2), 249-260. [in Chinese with English summary]

Zhao, Y.L., Yang, R.D., Yuan, J.L., Zhu, M.Y., Guo, Q.J., YANG, X.L. \& TAI, T.S. 2001. Cambrian stratigraphy at Balang, Guizhou Province, China: Candidate Section of a global unnamed and stratotype section for Taijiang Stage. Palaeoworld 13, 189-208.

Zhao, Y.L., Zhu, M.Y., Babcock, L.E. \& Peng, J. 2011. The Kaili Biota-Marine organisms from 508 million years ago. 251 pp. Guizhou Science and Technology Press, Guiyang.

Zhao, Y.L., Zhu, M.Y., Babcock L.E., Yuan, J.L., Parsley, R.L. \& Peng, J. 2005. Kaili Biota: a taphonomic window on diversification of metazoans from the basal Middle Cambrian: Guizhou, China. Acta Geologica Sinica (English Edition) 79(6), 751-765. DOI 10.1111/j.1755-6724.2005.tb00928.x

Zhou, Z.Y., Yuan, J.L., Zhang, Z.H., Wu, X.R. \& Yin, G.Z. 1979. The Cambrian bio-geographical realm divided in Guizhou Province, South China and adjacent to region. Journal of Stratigraphy 3(4), 258-271. [in Chinese]

Zhou, Z.Y., Yuan, J.L., Zhang, Z.H., Wu, X.R. \& Yin, G.Z. 1980. System and correlation of Cambrian stratigraphies in Guizhou, China. Journal of Stratigraphy 4(4), 273-281. [in Chinese] 